\title{
Analysis for price variations in fluoroquinolones eye preparations manufactured by various pharmaceutical companies
}

\author{
Akash Chandra ${ }^{1}$, Manish Kumar ${ }^{2}$, Shashank Kumar ${ }^{3, *}$ \\ ${ }^{1}$ Senior Resident, ${ }^{2}$ Assistant Professor, ${ }^{3}$ Senior Resident, ${ }^{\mathbf{1} 2}$ Dept of Pharmacology, Indira Gandhi Institute of Medical Sciences, \\ Sheikhpura, Patna, Bihar, ${ }^{3}$ Dept. of Medicine, All India Institute of Medical Sciences, Patna, Bihar, India
}

*Corresponding Author:

Email: shashankkr700@yahoo.in

\begin{abstract}
Introduction: Fluoroquinolone eye drops are prescribing by Ophthalmologist in many ocular diseases as conjunctivitis, keratitis, bacterial corneal ulcers etc in more and more amount. There are many brands of fluoroquinolones drugs available in Indian market. Costly drugs can lead to economic burden on patients. Modifications in pharmaceutical policy are required, and prices of the drug should be controlled in effective way for all the drugs. Hence this study was done to assess the cost variation of fluoroquinolones ophthalmic solutions available in Indian market.

Materials and Method: The maximum and minimum price of each brand of the drug in INR was noted by using CIMS January to April 2018 edition Drug Today April to June 2018 Vol-1. The cost ratio and the percentage cost variation for individual drug brands was calculated. The cost of each eye drop was calculated. At last the cost ratio and percentage cost variation of various brands was compared.

Result: Percentage variation in cost for fluoroquinolones eye preparations marketed in India was found to be Eye drop Ciprofloxacin $(0.3 \%)$ of $5 \mathrm{ml}: 210.39$, Eye drop Ciprofloxacin $(0.3 \%)$ of $10 \mathrm{ml}: 162$, Eye drop Gatifloxacin $(0.3 \%)$ of $5 \mathrm{ml}: 156$, Eye drop Moxifloxacin (0.5\%) of 5ml:196.95, Eye drop Ofloxacin (0.3\%) of 5ml:245.16,Eye drop Ofloxacin(0.3\%) of 10ml:62.5,Eye drop Norfloxacin( $0.3 \%$ ) of 5ml:120.68, Eye drop Sparfloxacin (0.3\%):8.31,Eye drop Lomefloxacin (0.3\%):16.17

Conclusion: There is a wide difference in the cost of different brands of fluoroquinolones eye preparations available in India. The clinicians prescribing these drugs should be aware of these variations in cost to reduce the cost of drug therapy.
\end{abstract}

Keywords: Fluoroquinolones, Percentage cost variation, Keratitis, Bacterial corneal ulcer, Conjunctivitis.

\section{Introduction}

Quinolone antibiotic comes under the group of broad-spectrum antimicrobials that share a bicyclic core structure related to the compound 4-quinolone. ${ }^{1}$ They are used in human and veterinary medicine to treat bacterial infections, as well as in animal husbandry. Nearly all quinolone antibiotics in modern use are fluoroquinolones, which contain a fluorine atom in their chemical structure and are effective against both Gramnegative and Gram-positive bacteria. One example is ciprofloxacin (Cipro), one of the most widely used antibiotics worldwide. ${ }^{2-3}$ Fluoroquinolones are often used for genitourinary infections and are widely used in the treatment of hospital-acquired infections associated with urinary catheters. In community-acquired infections, they are recommended only when risk factors for multidrug resistance are present or after other antibiotic regimens have failed. However, for serious acute cases of pyelonephritis or bacterial prostatitis where the patient may need to be hospitalized, fluoroquinolones are recommended as first-line therapy. ${ }^{4}$ Fluoroquinolones are featured prominently in guidelines for the treatment of hospitalacquired pneumonia. ${ }^{5}$ Quinolones and fluoroquinolones are chemotherapeutic bactericidal drugs, eradicating bacteria by interfering with DNA replication. Quinolones inhibit the bacterial DNA gyrase or the topoisomerase IV enzyme, thereby inhibiting DNA replication and transcription. Topoisomerase II is also a target for a variety of quinolone-based drugs. High activity against the eukaryotic type II enzyme is exhibited by drugs containing aromatic substituents at their C-7 positions. ${ }^{6}$ If tendonitis occurs, it generally appears within one month, and the most common tendon that is injured appears to be the Achilles tendon. ${ }^{7}$ Nervous system effects include insomnia, restlessness, and rarely, seizure, convulsions, and psychosis. ${ }^{8}$ Fluoroquinolones prolong the heart's QT interval by blocking voltage-gated potassium channels. ${ }^{9}$ Topical antibiotics are recommended in many ocular infections as bacterial corneal ulcer or conjunctivitis, keratitis, post-operative ocular surgery. ${ }^{10}$

\section{Materials and Method}

Price in INR of fluoroquinolones eye drops manufactured by different pharmaceutical companies in India, in the same or different strength was obtained from "Current Index of Medical Specialties" [CIMS] January to April- 2018 edition and Drug Today April to June 2018 edition, vol-1 as they are readily available source of drug information and are updated regularly.

The drug formulation being manufactured by only one company or being manufactured by different companies; however, in different strengths were excluded. Maximum and minimum Cost of the fluoroquinolones eye drops belong to different pharmaceutical companies was calculated. Difference in the maximum and minimum price of the same drug 
formulation manufactured by different pharmaceutical companies and percentage variation in price was calculated. Percentage cost variation was calculated as follows:

Percentage cost variation $=$ Maximum cost-Minimum cost/Minimum cost $\mathrm{x} 100$

Cost ratio $=$ Price of costliest brand/Price of least costly brand

\section{Result}

The analysis of data showed a large variation in costs of different brands of fluoroquinolones eye drops available In Indian market. Percentage variation in costs of fluoroquinolones eye drops marketed in India was found to be Ciprofloxacin (0.3\%) of $5 \mathrm{ml}: 210.39$, Ciprofloxacin (0.3\%) of $10 \mathrm{ml}: 162$, Gatifloxacin $(0.3 \%)$ of 5ml:156, Moxifloxacin (0.5\%) of $5 \mathrm{ml}: 196.95$, Ofloxacin $(0.3 \%)$ of $5 \mathrm{ml}: 245.16$, Ofloxacin $(0.3 \%)$ of 10ml:62.5, Norfloxacin (0.3\%) of 5ml:120.68, Sparfloxacin (0.3\%):8.31, Lomefloxacin (0.3\%):16.17.

Ofloxacin $(0.3 \%)$ eye drop of $5 \mathrm{ml}$ shows highest cost ratio and percentage cost variation as $3.45 \&$ 245.16 While Sparfloxacin $(0.3 \%)$ eye drop shows lowest cost ratio and percentage cost variation as 1.08 $\& 8.31$

Table 1: Drug costs, cost ratio and percentage cost variation of fluoroquinolones eye preparations available in Indian Market

\begin{tabular}{|l|c|c|c|c|c|c|}
\hline \multicolumn{1}{|c|}{$\begin{array}{c}\text { Drugs } \\
\text { [Eye Drops] }\end{array}$} & Dose & $\begin{array}{c}\text { No. of } \\
\text { brands }\end{array}$ & $\begin{array}{c}\text { Maximum } \\
\text { Price [Rs] }\end{array}$ & $\begin{array}{c}\text { Minimum } \\
\text { Price [Rs] }\end{array}$ & $\begin{array}{c}\text { Cost } \\
\text { Ratio }\end{array}$ & $\begin{array}{c}\text { Percentage } \\
\text { Cost Variation }\end{array}$ \\
\hline $\begin{array}{l}\text { Ciprofloxacin } \\
(0.3 \%)\end{array}$ & $5 \mathrm{ML}$ & 20 & 15.83 & 5.10 & 3.10 & 210.39 \\
\hline $\begin{array}{l}\text { Ciprofloxacin } \\
(0.3 \%)\end{array}$ & $10 \mathrm{ML}$ & 7 & 20.60 & 7.85 & 2.62 & 162 \\
\hline Gatifloxacin (0.3\%) & $5 \mathrm{ML}$ & 6 & 64.21 & 25.06 & 2.56 & 156 \\
\hline $\begin{array}{l}\text { Moxifloxacin } \\
(0.5 \%)\end{array}$ & $5 \mathrm{ML}$ & 30 & 117 & 39.40 & 2.96 & 196.95 \\
\hline Ofloxacin (0.3\%) & $5 \mathrm{ML}$ & 20 & 53.50 & 15.50 & 3.45 & 245.16 \\
\hline Ofloxacin (0.3\%) & $10 \mathrm{ML}$ & 13 & 32.50 & 20 & 1.62 & 62.5 \\
\hline Norfloxacin $(0.3 \%)$ & $5 \mathrm{ML}$ & 5 & 16 & 7.25 & 2.20 & 120.68 \\
\hline Sparfloxacin $(0.3 \%)$ & $5 \mathrm{ML}$ & 3 & 27.35 & 25.25 & 1.08 & 8.31 \\
\hline $\begin{array}{l}\text { Lomefloxacin } \\
(0.3 \%)\end{array}$ & $5 \mathrm{ML}$ & 2 & 27.30 & 23.50 & 1.16 & 16.17 \\
\hline
\end{tabular}

\section{Discussion}

People living in developing countries pay heavy cost of medicines. The Indian market has over 100,000 formulations and there is no system of registration of Medicines. More than one company sells a particular drug under different brand names apart from the innovator company. This situation has led to greater price variation among drugs marketed. These wide variations in the prices of different formulations of the same drug have severe economic implications in India. People in developing countries pay the cost of medicines out-of-pocket. In India, more than $80 \%$ health financing are borne by patients. Patients have to pay more unnecessarily if costly brands are prescribed. Many poor people frequently face a choice between buying medicines or buying food. In India, more than $80 \%$ health financing are borne by patients. ${ }^{11-13}$ The situation becomes more complex due to the presence of number of brands with variety of names and prices. ${ }^{14}$ The price variation assumes significance when the cost ratio exceeds 2 and percentage cost variation exceeds 100. By this fact the above analysis showed that cost ratio \& percentage cost variation of Ofloxacin $(0.3 \%$, $10 \mathrm{ml})$, Sparfloxacin $(0.3 \%, 5 \mathrm{ml})$, and Lomefloxacin $(0.3 \%, 5 \mathrm{ml})$ is below $2 \& 100$, so these drugs do not show significant price variation and these drugs can be prescribed in poor patients. Significant price variation creates economic burden on poor patients. Costs of drugs are controlled by the drug cost control order 2013(DPCO). ${ }^{15}$ Hence, we need to draw attention to the prices of various drug formulation brands available to reduce the cost of therapy. ${ }^{16}$ The treating physician should be made aware of the cheapest drug available among the various brands so that the patient bears lesser burden of treatment cost. ${ }^{17}$ In India, doctors have less awareness in the cost difference of different brands of the same drug. It is felt that physicians could provide better services and reduce costs of drugs if information about drug prices was readily available.

\section{Conclusion}

In now days prices of few drugs are under government control through DPCO [Drug price control order]. Hence the physician should always remember that he should not avoid treating the patients with a particular drug because it is expensive and should rather balance his therapeutic decisions in prescribing a particular drug by considering the patients socioeconomic status. There is a strong need to create awareness about this huge price variation among the 
general public, health care providers, health care payers, government agencies, policy makers, pharmacists for appropriate intervention to reduce economic burden on patients as well as the healthcare system.

\section{References}

1. Andriole, VT The Quinolones. Academic Press, 1989.

2. Andersson MI, MacGowan AP (2003). "Development of the quinolones". Journal of Antimicrobial Chemotherapy. 51 (Suppl. S1): 1-11. doi:10.1093/jac/dkg212.

3. Heeb, S.; Fletcher, M. P.; Chhabra, S. R.; Diggle, S. P.; Williams, P.; Cámara, M. (2011). "Quinolones: from antibiotics to autoinducers" (PDF). FEMS Microbiology Reviews. 35 (2): 247-274. doi:10.1111/j.15746976.2010. 00247. x. PMC 3053476 . PMID 20738404.

4. Liu, H.; Mulholland, SG. (July 2005). "Appropriate antibiotic treatment of genitourinary infections in hospitalized patients". American Journal of Medicine. 118 Suppl 7A (7):14S-20S. doi:10.1016/j.amjmed.2005.05.009. PMID 15993673.

5. "Guidelines for the management of adults with hospitalacquired, ventilator-associated, and healthcare-associated pneumonia". American Journal of Respiratory and Critical Care Medicine. 171 (4): 388-416. February 2005. doi:10.1164/rccm. 200405-644ST. PMID 15699079

6. Elsea, SH.; Osheroff, N.; Nitiss, JL. (July 1992). "Cytotoxicity of quinolones toward eukaryotic cells. Identification of topoisomerase II as the primary cellular target for the quinolone CP-115,953 in yeast" (PDF). J Biol Chem. 267 (19): 13150-3. PMID 1320012. Retrieved 6 May 2011

7. Stephenson, AL; Wu, W; Cortes, D; Rochon, PA (September 2013). "Tendon Injury and Fluoroquinolone Use: A Systematic Review". Drug safety.36(9):709-21. doi:10.1007/s40264-013-0089-8. PMID 23888427

8. Galatti L, Giustini SE, Sessa A, et al. (March 2005). "Neuropsychiatric reactions to drugs: an analysis of spontaneous reports from general practitioners in Italy". Pharmacological Research. 51(3):211-6.

doi:10.1016/j.phrs.2004.08.003. PMID 15661570

9. Heidelbaugh JJ, Holmstrom H (April 2013). "The perils of prescribing fluoroquinolones". The Journal of Family Practice. 62(4):191-7. PMID 23570031.

10. [Guideline] AAO Cornea/External Disease PPP Panel, Hoskins Center for Quality Eye Care. Conjunctivitis PPP. ONE Network. Available at http://www.aao.org/preferred-practicepattern/conjunctivitis-ppp--2013. 2013

11. Thomas M. Rational drug use and essential drug concept. In Parthasarthi G, Ny fort Hasen K, Editors.A Text book of Clinical Pharmacy Practice. Ist Ed. Himayatnagar, Hyderabad: Orient Longman;2004:723.

12. Creese A, Kotwani A, Kutzin J, Pillay A. Evaluating pharmaceuticals for health policy in low and middle income country settings. In; Freemantle N, Hills, eds. Evaluating Pharmaceuticals for Health policy and reimbursement. Massachusetts, USA: B lackwell Publication;(in collaboration with WHO Geneva);2004:227-43.

13. Mahal A, Karan A, Engelgau M. The Economic Implications of Non-Communicable Disease for India. Washington, DC: World Bank. 2010. Available at http://siteresourses.world bank.org/HEALTHNUTRITIONANDPOPULATION/Re sourses/281627-1095698140167/ Economic Implications of NCD for India.pdf.
14. Rataboli PV, Garg A. Confusing brand names: nightmare of medical profession. J Postgrad Med.2005;51:13-6.

15. Drug cost control order, 2013 Government of India. Available at http://www.nppaindia.nic.in/DPCO2013.pdf

16. Vieira JL, Portal VL, Moriguchi EH. How much do we pay for a benefit? A descriptive cost analysis of the use of statins. The need for a national cost -effectiveness analysis.ArqBras Cardiol .2001; 76(5):409-18

17. Kumar L et al. cost variation analysis of antimalarial drugs available in India. Int J Res Med Sci.2017 Sep;5(9):4051-4. 